\title{
DAYA ANTIBAKTERI EKSTRAK ETANOL DAUN KUBIS (Brassica oleracea var.capitata f.alba) TERHADAP BAKTERI Escherichia coli SECARA IN VITRO
}

\author{
Siti Fatimah, Yuliana Prasetyaningsih, Riska Amelia \\ 1,2,3Prodi D3 Analis Kesehatan STIKes Guna Bangsa Yogyakarta; JI.Ringroad Utara \\ Depok Sleman Yogyakarta, telp/Fax:(0274)4477701/(0274)4477702 \\ e-mail: 1'siti fatimah@gunabangsa.ac.id
}

\begin{abstract}
Background :. Escherichia coli is a bacteria cause of infections such as diarhea and urinary tractus infection. Antibiotic used for treatment of diarhea and urinary tractus infection include ampicilin, penicilin G, amoxicilin, chloramphenicol, tetracycline, and sulbenicin. These antibiotic are often used, but it has some side effects as well as the emergence of resistance. Treatment with minimal effects and does not cause mildew resistance continue to alternative antibacteria. Cabbage leaf is a vegetable which contains flavonoid, saponin, polifenol, and tanin that are antibacteria. The purpose of this study was to determine antibacteria effectivity ethanol extract of cabbage leaf (Brassica oleracea var.capitata f.alba) againts Escherichia coli bacteria in vitro.
\end{abstract}

Method : This research is an experimental study with the method of diffusion (Kirby Bauer). Escherichia coli bacteria isolated obtained from Medical Laboratory Technology of Poltekkes Kemenkes Yogyakarta. Ethanol extract obtained through maseration extraction method and the concentration used were $60 \%, 70 \%, 80 \%, 80 \%, 90 \%$, and $100 \%$. Analysis of the research results in table and narration.

Results : The results of inhibition zone is formed at a concentration of $60 \%, 70 \%, 80 \%, 90 \%$, and $100 \%$ respectively are $11,33 \mathrm{~mm}, 12,33 \mathrm{~mm}, 13 \mathrm{~mm}, 14,33 \mathrm{~mm}$, and $15 \mathrm{~mm}$.).

Conclusion : Ethanol extract of cabbage leaf (Brassica oleracea var.capitata f.alba) are antibacteria againts Escherichia coli bacteria with strong category in (10-20 mm).

Keywords : Escherichia coli, antibacteria, flavonoid, saponin, polyphenol, tanin, cabbage leaf (Brassica oleracea var.capitata f.alba)

\section{PENDAHULUAN}

Penyakit infeksi masih menempati urutan teratas penyebab kesakitan dan kematian di negara berkembang termasuk Indonesia.Salah satu penyebab infeksi adalah bakteri. Kasus infeksi disebabkan oleh bakteri atau mikroorganisme patogen yang masuk ke dalam jaringan tubuh dan berkembang biak di dalam jaringan (Permenkes RI, 2011). Salah satu penyebab infeksi adalah Escherichia coli.Escherichia coli merupakan anggota flora usus normal yang pada umumnya tidak menyebabkan penyakit. $E$. coli sering dihubungkan dengan diare yang terjadi pada manusia.Tempat yang paling sering terkena infeksi adalah saluran kemih, saluran empedu, dan tempat-tempat lain di rongga perut (Jawetz dan Adelberg, 2005).

Kasus penyakit diare masih menjadi masalah kesehatan dunia terutama di negara berkembang. Masalah tersebut dilihat dari besarnya angka kesakitan dan kematian akibat diare.Survey morbiditas yang dilakukan oleh Departemen 
Kesehatan dari tahun 2000 sampai dengan tahun 2010 terlihat kecenderungan kenaikan insiden. Pada tahun 2000 insiden penyakit Diare 301/1000 penduduk, tahun 2003 naik menjadi 374/1000 penduduk, tahun 2006 naik menjadi 423/1000 penduduk dan tahun 2010 menjadi 411/1000 penduduk (Depkes RI, 2010). Data dari profil kesehatan tahun 2013 menunjukkan kejadian luar biasa (KLB) di 33 provinsi dengan Case Fatality Rate (CFR) akibat diare sebesar $1,08 \%$ dengan 7 orang meninggal dari 646 kasus. Angka ini lebih tinggi jika dibandingkan dengan tahun 2011, yaitu CFR sebesar 0,29\% dengan 12 orang meninggal dari 4.169 kasus KLB diare yang terjadi pada 33 provinsi (Kemenkes RI, 2014).

Menurut Refdanita dkk, (2004), penyakit infeksi termasuk oleh bakteri Escherichia coli dapat diobati dengan menggunakan obat antibiotik. Escherichia coli mempunyai tingkat resistensi yang tinggi terhadap ampisilin, penisilin $G$, amoksisilin, kloramfenikol, tetrasiklin dan sulbenisin. Oleh karena itu, perlu dilakukan eksplorasi terhadap bahan alternatif yang dapat membasmi atau menghambat pertumbuhan bakteri patogen (Sudoyo, dkk., 2006).

Indonesia adalah negeri yang cukup kaya akan kekayaan alam. Sejak dulu, masyarakat Indonesia telah lama mengenal dan menggunakan tanaman berkhasiat obat sebagai salah satu upaya dalam menanggulangi masalah kesehatan.Dewasa ini perkembangan pengobatan telah mengarah kembali ke alam (Back to nature) karena obat tradisional secara umum dinilai lebih aman daripada penggunaan obat modern.Hal ini disebabkan karena obat tradisional memiliki efek samping yang relatif sedikit daripada obat modern (Sari dan Lusia, 2006).Saat ini telah banyak dikembangkan obat tradisional dari tumbuhan, salah satunya adalah Kubis (Brassica oleracea var.capitata L).Kubis merupakan salah satu hasil bumi Indonesia yang jumlahnya sangat berlimpah.Sementara itu, selama ini kubis hanya dikonsumsi sebagai sayuran. Dengan demikian kubis dapat dimanfaatkan sebagai alternatif antibakteri dan memberikan nilai manfaat yang tinggi bagi masyarakat. Berdasarkan penggunaannya sebagai sayuran yang dikonsumsi sehari-hari, maka zat aktif antibakteri yang terkandung dalam kubis dapat dikatakan aman untuk digunakan oleh manusia (Suryani, 2004).

Kubis,saat ini telah digunakan dalam berbagai pengobatan seperti pirai (gout), diare, tuli, sakit kepala, kolesterol, candidiasis, jamur di kulit kepala, tangan dan kaki, radang sendi (artritis), antidot akibat alkohol, racun di hati, menghilangkan keluhan prahaid, mencegah tumor membesar, mencegah kanker kolon dan rektum, ulkus pada saluran cerna, dan sembelit (LIPI, 2009). Kubis mentah tidak memiliki rasa dan bau yang menyenangkan karena kandungan sulfurnya.Tetapi, sulfur memiliki sifat antiseptik, antibiotik dan desinfektan.Dari penelitian yang dilakukan oleh Rusmiati, dkk (2007), didapatkan kandungan dalam kubis (Brassica oleracea var.capitata $L$ ) berupa flavonoid, saponin, polifenol, tanin yang mempunyai sifat antibakteri. Mekanisme kerja flavonoid sebagai antibakteri adalah dengan menghambat sintesis DNA, mengganggu fungsi dari membran sitoplasma dan menghambat transfer energi yang diperlukan untuk metabolisme bakteri (Cushine dan Lamb, 2005). Menurut Supriyono (2008), polifenol adalah asam fenolik dan flavonoid yang banyak terkandung dalam buah-buahan, sayuran serta biji-bijian.Selain itu, senyawa fenol juga diketahui memiliki sifat antibakteri, antivirus, antimutagenik, dan antikarsinogenik. Adanya kandungan dari senyawa flavonoid, saponin, polifenol sebagai senyawa antibakteri pada kubis sangat potensial untuk dimanfaatkan sebagai terapi terhadap infeksi bakteri termasuk $E$. coli, sehingga peneliti tertarik untuk meneliti daya antibakteri ekstrak etanol daun kubis (Brassica olerace var.capitata $f$. alba) terhadap bakteri Escherichia coli secara in vitro. Penelitian ini diharapkan dapat dijadikan sebagai solusi dari peningkatan kasus resistensi antibiotik terhadap bakteri Escherichia coli.

\section{METODE PENELITIAN}

Jenis penelitian yang digunakan adalah penelitian True Eksperimental. Sedangkan rancangan yang digunakan 
adalah Post test Only Control (Rancangan Post tes dengan kelompok kontrol). Dengan rancangan ini, memungkinkan peneliti mengukur pengaruh perlakuan (intervensi) pada kelompok eksperimen dengan cara membandingkan kelompok tersebut dengan kelompok kontrol .

Bahan : daun kubis (Brassica oleracea var.capitata $f$. alba), Suspensi bakteri Escherichia coli, Cakram antibiotik Kloramphenikol

Media dan Reagensia : $\mathrm{NaCl}$ fisiologis 0,85\%, Media Mueller Hinton, Standar Mc Farland I (setara dengan $10^{6} \mathrm{CFU}$ ), Polyetilene Glycol (PEG) 5\%.

Peralatan: tabung reaksi steril, ose bulat, incubator, cawan petri, pipet ukur steril, neraca atau timbangan, oven, gelas beker steril, autoclave, pervorator, pipet tetes.

\section{Tahap Pelaksanaan Penelitian}

\section{a. Pemilihan sampel daun kubis}

Daun kubis yang digunakan, didapatkan dari perkebunan kubis di Banyuroto, Sawangan, Kabupaten Magelang, Jawa Tengah dengan kualitas daun kubis yang segar dan putih bersih serta sehat tidak cacat akibat hama tanaman

\section{b. Pembuatan Ekstrak etanol daun kubis}

Metode ekstraksi yang dipakai dalam penelitian ini adalah metode maserasi. Sebelumnya, daun kubis dengan berat $3 \mathrm{~kg}$ dipisah-pisah dari kropnya dan dikeringkan di dalam almari pengering suhu $45^{\circ} \mathrm{C}$ hingga kering, kemudian dihaluskan menjadi serbuk menggunakan mesin penyerbuk dengan diameter lubang saringan 1 $\mathrm{mm}$. Serbuk kubis yang telah kering dimasukkan ke dalam maserator, ditambahkan etanol 50\%. Diaduk selama 30 menit, didiamkan 24 jam, kemudian disaring (diulang 2 kali). Setelah itu filtrat diuapkan dengan Vacuum Rotary Evaporator pemanas waterbath suhu $60^{\circ} \mathrm{C}$ sehingga diperoleh ekstrak etanol daun kubis yang kental sebanyak 53,8 gram dari 3 $\mathrm{kg}$ kubis yang digunakan

\section{c. Pembuatan konsentrasi ekstrak etanol daun kubis}

Ekstrak etanol daun kubis (Brassica oleracea var.capitata f.alba) diencerkan dengan PEG (Polyetilene Glycol) 5\% menjadi konsentrasi $60 \%, 70 \%, 80 \%$, $90 \%$ dan $100 \%$. Pengenceran dilakukan dengan menyiapkan tabung reaksi dan dilakukan secara aseptik dengan volume sesuai dengan Tabel 1.

Tabel 1. Pengenceran Ekstrak Etanol Daun Kubis (Brassica oleraceavar.capitata f.alba)

\begin{tabular}{lccccc}
\hline \multicolumn{1}{c}{ Pengenceran } & $60 \%$ & $70 \%$ & $80 \%$ & $90 \%$ & $100 \%$ \\
\hline Ekstrak etanol daun kubis (ml) & $0,6 \mathrm{ml}$ & $0,7 \mathrm{ml}$ & $0,8 \mathrm{ml}$ & $0,9 \mathrm{ml}$ & $3,0 \mathrm{ml}$ \\
Add PEG (Polyetilene Glycol) $5 \%(\mathrm{ml})$ & $0,4 \mathrm{ml}$ & $0,3 \mathrm{ml}$ & $0,2 \mathrm{ml}$ & $0,1 \mathrm{ml}$ & $0,0 \mathrm{ml}$ \\
Volume (ml) & $1 \mathrm{ml}$ & $1 \mathrm{ml}$ & $1 \mathrm{ml}$ & $1 \mathrm{ml}$ & $3 \mathrm{ml}$ \\
\hline
\end{tabular}

\section{d. Pelaksanaan Penelitian Uji} Efektivitas Antibakteri

Uji daya antibakteri ekstrak etanol daun kubis (Brassica oleraceavar.capitata f.alba) dilakukan dengan metode difusi. Disediakan 4 petri untuk pengujian dan pengulangan. Petri $A, B, C$ dibuat 5 sumuran, pada masing-masing sumuran tersebut diisi dengan ekstrak etanol daun kubis $60 \%, 70 \%, 80 \%, 90$ dan $100 \%$ petri $D$ dibuat 1 sumuran untuk kontrol negatif (sumuran diberi PEG 5\%) dan untuk kontrol positif (diberi cakram antibiotik kloramphenikol). Pengujian dilakukan dengan lidi kapas steril yang dicelupkan ke dalam biakan cair kuman kemudian lidi kapas yang telah basah diperas pada dinding tabung.Selanjutnya lidi kapas tersebut diusapkan pada seluruh permukaan media agar Mueller Hinton.Pada agar tersebut dibuat sumuran dengan perforator secara aseptik.Tiap sumuran mempunyai diameter $5 \mathrm{~mm}$ dan kemudian ke dalam sumuran tersebut diteteskan ekstrak etanol kubis dengan beberapa konsentrasi 
yang telah dibuat yaitu $60 \%, 70 \%$, $80 \%, 90 \%$ dan $100 \%$. Media tersebut diinkubasi $37^{\circ} \mathrm{C}$ selama 24 jam. Hasil diperoleh dengan mengukur radius zona hambatan perumbuhan koloni E.coli pada media Mueller Hinton yang kemudian di rata-rata diameternya.

\section{HASIL DAN PEMBAHASAN}

Penelitian dengan judul "Efektivitas Antibakteri Ekstrak Etanol Daun Kubis (Brassica oleracea var.capitata f.alba) Terhadap Bakteri Escherichia coli Secara In Vitro telah dilakukan pada bulan Maret 2015 di Laboratorim Mikrobiologi Politeknik Kesehatan Yogyakarta Jurusan Analis Kesehatan. Penelitian tersebut merupakan penelitian awal yang dilakukan untuk mengetahui daya antibakteri ekstrak etanol daun kubis terhadap bakteri Escherichia coli, sehingga dapat diketahui efek antibakteri terhadap konsentrasi ekstrak etanol daun kubis yang diberikan.

Daun kubis yang digunakan berasal dari perkebunan kubis di Banyuroto, Sawangan, Kabupaten Magelang, Jawa Tengah dengan kriteria kubis sehat, segar, tidak cacat karena hama tanaman.
Ekstraksi daun kubis dilakukan menggunakan metode maserasi dengan pelarut etanol 50\%, sehingga menghasilkan ekstrak kental 100\% yangyang kemudian dibuat menjadi berbagai konsentrasi yaitu 100\%, 90\%, $80 \%, 70 \%$, dan $60 \%$. Uji daya antibakteri menggunakan berbagai konsentrasi ekstrak etanol daun kubis tersebut serta menggunakan PEG 5\% dan Kloramfenikol sebagai pembanding kontrol positif dan negatif.

Pengujian daya antibakteri bertujuan untuk mengetahui kemampuan antibakteri dalam menghambat atau membunuh bakteri.Pada penelitian ini menggunakan metode difusi (tes Kirby-Bauer). Adanya zona bening di sekitar sumuran menunjukkan aktivitas antibakteri. Diameter zona bening di sekitar sumuran yang berisi ekstrak diukur dan dibandingkan dengan diameter zona jernih di sekitar cakram kontrol positif (kloramfenikol) dan kontrol negatif (PEG $5 \%$ ). Hasil uji daya antibakteri daun kubis yang telah dilakukan, memiliki kemampuan dalam menghambat pertumbuhan bakteri Escherichia coli yang ditunjukkan pada tabel 2 berikut:

Tabel 2. Data hasil pengukuran diameter zona hambat pertumbuhan Escherichia coli terhadap pemberian berbagai konsentrasi ekstrak etanol daun kubis (Brassica oleracea var.capitataa

\begin{tabular}{|c|c|c|c|c|c|}
\hline \multirow[t]{2}{*}{ No } & \multirow{2}{*}{$\begin{array}{c}\text { Konsentrasi Ekstrak Etanol Daun } \\
\text { Kubis }\end{array}$} & \multicolumn{3}{|c|}{ Zona hambat (mm) } & \multirow{2}{*}{$\begin{array}{l}\text { Rata-rata zona hambat } \\
\qquad(\mathrm{mm})\end{array}$} \\
\hline & & $A$ & $\mathrm{~B}$ & C & \\
\hline 1. & $60 \%$ & 12 & 11 & 11 & 11,33 \\
\hline 2. & $70 \%$ & 13 & 12 & 12 & 12,33 \\
\hline 3. & $80 \%$ & 14 & 12 & 13 & 13 \\
\hline 4. & $90 \%$ & 14 & 13 & 16 & 14,33 \\
\hline 5. & $100 \%$ & 16 & 15 & 14 & 15 \\
\hline 6. & Kloramfenikol & & 25 & & 25 \\
\hline 7. & PEG 5\% & & 0 & & 0 \\
\hline
\end{tabular}


Zona hambat yang terbentuk dapat dilihat pada Gambar 1 berikut:

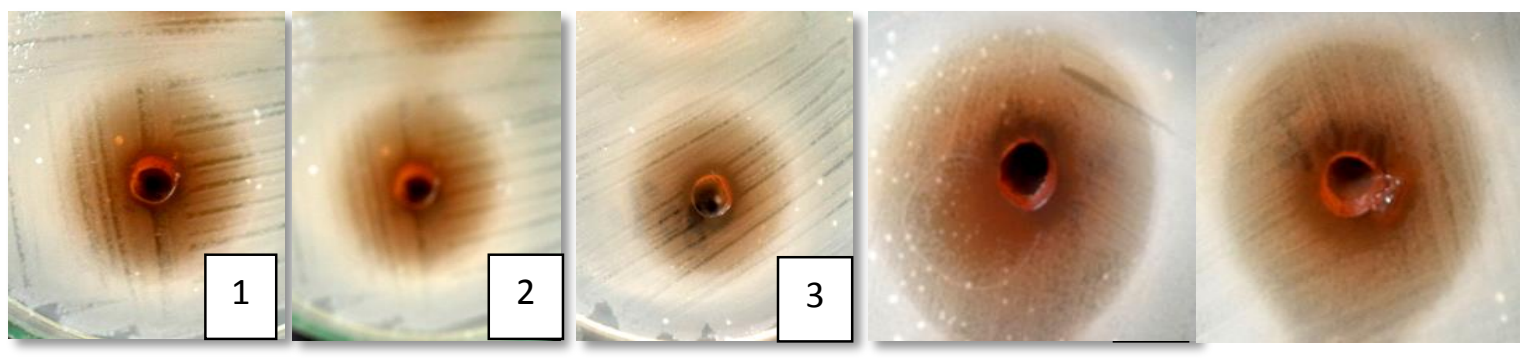

Gambar 1. Zona Hambat Ekstrak Etanol Daun Kubis pada media MuellerHinton dengan Variasi Konsentrasi Terhadap Escherichia coli.konsentrasi 60\% (1), konsentrasi 70\% (2), konsentrasi $80 \%(3)$, konsentrasi $90 \%(4)$, konsentrasi 100\% (5).

Berdasarkan hasil penelitian didapatkan bahwa, konsentrasi ekstrak etanol daun kubis dengan tiga kali pengulangan terhadap bakteri Escherichiacoli mampu menghambat pertumbuhan bakteri Escherichia coli dimulai dari konsentrasi $60 \%$ hingga $100 \%$.Semakin tinggi konsentrasi ekstrak etanol daun kubis maka semakin besar diameter zona jernih yang terbentuk.

$$
\text { Antibakteri merupakan suatu }
$$
senyawa yang mampu menghambat ataupun membunuh mikroorganisme dalam konsentrasi yang kecil.Daya antibakteri dapat dipengaruhi oleh konsentrasi zat uji, jumlah bakteri, adanya bahan organik, dan $\mathrm{pH}$ (Pelzcar and Chan, 2005). Menurut Stout dalam Maryuni (2008), daya antibakteri dikelompokkan ke dalam 3 kelompok, yaitu antibakteri dengan aktivitas rendah, sedang, kuat dan sangat kuat dapat dilihat pada tabel 3 .

Tabel 3. Pengelompokkan aktivitas antibakteri menurut Stout

\begin{tabular}{cc}
\hline Aktivitas & Diameter Zona Hambat (mm) \\
\hline Rendah & $<5$ \\
Sedang & $5-10$ \\
Kuat & $10-20$ \\
Sangat Kuat & $>20$ \\
\hline
\end{tabular}

Sumber : Stout dalam Maryuni (2008)

Hasil penelitian yang diperoleh apabila dikaitkan dengan ketentuan seperti pada tabel 3 dengan ketentuan kekuatan antibakteri yang dikemukakan oleh Stout, maka kekuatan antibakteri yang terkandung dalam ekstrak etanol daun kubis dengan konsentrasi $60 \%, 70 \%, 80 \%$, $90 \%$, dan $100 \%$ masuk dalam kategori kuat (masuk dalam kisaran 10-20 mm), yaitu dengan masing-masing diameter zona hambat $11,33 \mathrm{~mm}, 12,33 \mathrm{~mm}, 13 \mathrm{~mm}$, $14,33 \mathrm{~mm}$ dan $15 \mathrm{~mm}$.

Hasil tersebut menunjukkan bahwa meningkatnya konsentrasi ekstrak etanol daun kubis juga meningkatkan diameter zona hambat.Semakin tinggi konsentrasi ekstrak, maka jumlah senyawa antibakteri yang dilepaskan semakin besar, sehingga kemampuan senyawa tersebut dalam menghambat pertumbuhan bakteri juga meningkat. Aktivitas antibakteri tersebut diduga berkaitan dengan senyawa aktif yang terkandung di dalam daun kubis, antara lain flavonoid, polifenol, saponin dan tanin (Rusmiati, dkk., 2007).

Flavonoid memiliki aktivitas antibakteri melawan Staphylococcus epidermidis, Staphylococcus aureus, Escherichia coli, Salmonellatyphimurium, dan Stenotrophomonas maltophilia. Beberapa teori menyatakan bahwa mekanisme kerja flavonoid sebagai antibakteri adalah dengan menghambat sintesis DNA, mengganggu fungsi dari membran sitoplasma dan menghambat transfer energi yang diperlukan untuk metabolisme bakteri (Cushine dan Lamb, 2005).Polifenol mempunyai mekanisme 
menghambat pertumbuhan bakteri dengan cara mengganggu pembentukan dinding sel dan membran sel. Tanin mampu menghambat aktivitas kerja enzim pada bakteri, yaitu dengan cara mengikat dan mengendapkan protein pada mukus dan sel epitel mukosa. Senyawa saponin dapat melakukan mekanisme penghambatan dengan cara membentuk senyawa kompleks dengan membran sel melalui ikatan hidrogen sehingga dapat menghancurkan sifat permeabilitas dinding sel dan akhirnya dapat menimbulkan kematian sel ( Noer dan Nurhayati, 2006).

Hasil penelitian yang didapatkan berhubungan dengan penelitian yang dilakukan oleh Rosyad (2012) yang menyatakan bahwa kandungan senyawa kimia di dalam esktrak etanol pare (Momordica charantia L) seperti flavonoid, saponin, tanin dan polifenol dapat menghambat pertumbuhan bakteri Escherichia coli, di dalam ekstrak etanol daun kubis (Brassica oleraceavar.capitata f.alba) juga diduga mengandung senyawa kimia yang sama sehingga dapat menghambat pertumbuhan bakteri Escherichia coli. Hasil penelitian yang didapatkan apabila dikaitkan dengan penelitian yang dilakukan oleh Rusmiati, dkk (2007) dan Mita, dkk (2009) membuktikan bahwa ekstrak etanol daun kubis (Brassica oleracea var.capitataf.alba) tidak hanya dapat menghambat pertumbuhan jamur Candida albicans dan Malassezia furfur, namun dapat juga menghambat pertumbuhan bakteri yaitu bakteri Escherichia coli.

\section{KESIMPULAN DAN SARAN}

\section{A.Kesimpulan}

Ekstrak etanol daun kubis konsentrasi $60 \%, 70 \%, 80 \%, 90 \%$, dan $100 \%$ memiliki daya antibakteri dengan kategori kuat (10-20 mm), dengan diameter zona hambat $11,33 \mathrm{~mm}, 12,33$ $\mathrm{mm}, 13 \mathrm{~mm}, 14,33 \mathrm{~mm}$ dan $15 \mathrm{~mm}$

\section{B.Saran}

Perlu dilakukan penelitian lebih lanjut mengenai penggunakan ekstrak etanol daun kubis menggunakan jenis kubis yang berbeda, seperti kubis merah-ungu (forma rubra) dan kubis hijau (forma viridis

\section{DAFTAR PUSTAKA}

Cushine, T. P. T., Lamb, A. J. 2005. "Antimicrobial Activity of Flavonoid".International Journal of Antimicrobial Agents. 26: 343, 356.

Depkes RI. 2010. Profil Kesehatan Indonesia 2010. Departemen Kesehatan RI. Jakarta.

Jawetz dan Adelberg, 2005.Mikrobiologi Kedokteran, EGC. Jakarta.

Kemenkes RI. 2014. Profil Kesehatan Indonesia $2014 . \quad K e m e n t r i a n$ Kesehatan RI. Jakarta.

LIPI.2009. Tanaman Obat Pangan dan Kesehatan. Balai Informasi Teknologi LIPI. Jakarta.

Mita R. S, Rusmiati D, Kusuma S. A. F. 2009. "Pengembangan Ekstrak Etanol Kubis (Brassica oleraceavar.capitata I.) Asal Kabupaten Bandung Barat dalam Bentuk Shampo Antiketombe Terhadap Jamur Malassezia furfur", LPPM. Universitas Padjajaran. Bandung.

Noer, I. S. Dan L. Nurhayati. 2006. "Bioaktivitas Ulva reticulata Forsskal. Asal Gili Kondo Lombok Timur Terhadap Bakteri". Jurnal Biotika, vol. 5, No. 1. 2006., Hal. 45-60.

Refdanita, Maksum, Nurgan, Endang. 2004. Pola Kepekaan Kuman Terhadap Antibiotika Di Ruang Rawat Intensif Rumah Sakit Fatmawati Jakarta Tahun 2001-2002. Makara, Kesehatan, vol. 8, no. 2, Desember 2004: 41- $48 . \quad$ (online). http://repository.ui.ac.id/dokumen/lihat 182.pdf. Diunduh pada tanggal 16 September 2014.

Rosyad, F. 2012. "Uji Aktivitas Antibakteri Ekstrak Etanol Pare (Momordica charantia L.) Terhadap Pertumbuhan Escherichia coli Secara In Vitro". 
Skripsi. Fakultas Kedokteran Universitas Jember. Jember.

Rusmiati, D, Agung, Yasmiwar, Sulistianingsih. 2007. "Pemanfaatan Kubis (Brassicaoleracea var.capitata L) Sebagai Kandidat Antikeputihan". Jurnal. Universitas Padjajaran. Bandung.

Sari, Lusia O. R. K. 2006."Pemanfaatan Obat Tradisional Dengan Pertimbangan Manfaat dan Keamanannya". Majalah IImu
Kefarmasian, vol. III, No. 1, April 2006 : 01-07.

Stout dalam Maryuni. 2008. Aktivitas Antibakteri Tanaman Bandotan (Agerantum conyzoides Linn.) Terhadap Bakteri Escherichia coli dan Staphylococcus aureus.Karya Tulis IImiah. IPB. Bandung.

Sudoyo, W. A, Setyohadi B, dan Alwi I. 2006. Ilmu Penyakit Dalam. Departemen IImu Penyakit Dalam UI. Jakarta. 